\title{
Kapang endofit sebagai sumber senyawa aktif antivirus yang menjanjikan: Suatu Kajian Pustaka
}

\author{
Endophytic fungi as a promising source of antiviral active compounds: \\ A Review
}

Eris Septiana*

Puslit Bioteknologi LIPI, JL. Raya Bogor KM 46, Bogor, Indonesia, 16911

*Email:septiana.eris@gmail.com

Diterima 21 April 2020 Disetujui 28 Mei 2020

\section{INTISARI}

Infeksi virus masih menjadi masalah di seluruh negara di dunia. Vaksinasi dan penggunaan obat-obatan antivirus masih terus dilakukan sebagai upaya untuk menanggulangi infeksi virus. Kemunculan serotipe virus baru yang resisten terhadap obat antivirus yang ada telah meningkatkan usaha pencarian senyawa antivirus baru dari alam. Kapang endofit merupakan salah satu sumber senyawa antivirus yang sangat melimpah di alam. Beberapa senyawa antivirus yang aktif terhadap beberapa jenis virus penyebab infeksi pada manusia telah diisolasi dari kapang endofit. Senyawa emodin dari kapang endofit Aspergillus versicolor, aspergillipeptides $D$ dari Aspergillus sp., dan altertoxin $V$ dari Alternaria tenuissima masingmasing memiliki aktivitas antivirus terhadap virus hepatitis $\mathrm{C}$, herpes, dan HIV melalui pengujian secara in vitro. Sedangkan senyawa katekin dari Annulohypoxylon ilanense, norquinadoline A dari Cladosporium sp., dan isochaetochromin D1 dari Fusarium sp. memiliki aktivitas penghambatan terhadap SARS-CoV-2 secara in silico. Pengembangan senyawa aktif antivirus dari kapang endofit perlu ditingkatkan. Pengembangan meliputi pemilihan metode isolasi senyawa aktif yang optimal, penelitian lebih lanjut tentang mekanisme kerja senyawa antivirus, pengujian secara in vivo hingga uji pre klinis dan klinis. Pengembangan senyawa antivirus dari kapang endofit yang optimal diharapkan akan menghasilkan obat antivirus baru yang lebih efektif dalam pengobatan terhadap infeksi virus.

Kata kunci: antivirus, infeksi, kapang endofit, mekanisme aksi, senyawa aktif

\begin{abstract}
Viral infections are still a problem in all countries. Vaccination and antiviral drugs are still being done as an effort to tackle viral infections. The emergence of new virus serotypes that are resistant to existing antiviral drugs has increased the search for new natural antiviral compounds. Endophytic fungi are one of the potential sources of antiviral which is abundant in nature. Several antiviral compounds that are active against several types of viruses that cause infections in humans have been isolated from endophytic fungi. Emodin from endophytic fungi Aspergillus versicolor, aspergillipeptides D from Aspergillus sp., and altertoxin $\mathrm{V}$ from Alternaria tenuissima have in vitro antiviral activity against the Hepatitis $\mathrm{C}$, Herpes Simplex, and Human Immunodeficiency viruses respectively. While the catechin from Annulohypoxylon ilanense, norquinadoline A from Cladosporium sp., and isochaetochromin D1 from Fusarium sp. have in silico SARS-CoV-2 inhibitory activity. The development of antiviral active compounds from endophytic fungi needs to be improved. The development includes the optimal method of isolating active compounds, the mechanism of action, in vivo assay to pre-clinical and clinical trials. Optimal development of antiviral
\end{abstract}


compounds from endophytic fungi is expected to produce new antiviral drugs that are more effective in the treatment of viral infections.

Keywords: active compounds, antivirus, endophytic fungi, infection, mechanism of action

\section{PENDAHULUAN}

Virus menyebabkan wabah serius di semua negara yang menyebabkan kematian dan beban ekonomi yang sangat besar bagi masyarakat. Kemunculan serotipe baru secara konstan di kelompok virus yang memiliki tingkat mutasi tinggi serta masih adanya mekanisme perbanyakan virus yang belum dipahami menambah tantangan dalam melawan infeksi akibat virus (Linnakoski et al., 2018). Pengembangan vaksin terhadap berbagai serotipe virus yang baru muncul menjadi sebuah tantangan, karena saat ini vaksin hanya tersedia untuk sebagian kecil virus saja. Selain itu, vaksinasi tidak dapat membantu jika infeksi sudah terjadi. Untuk mengobati infeksi virus yang telah terjadi, penggunaan obat antivirus lebih sesuai untuk dilakukan. Obat antivirus bekerja menghambat infeksi virus secara khusus, diantaranya dengan menargetkan protein virus atau sel inang yang dieksploitasi oleh virus untuk reproduksi mereka (Clercq, 2002).

Oleh karena ketatnya prasyarat yang harus dilalui oleh kandidat obat antivirus, maka hanya beberapa obat antivirus sintetis saja yang telah berhasil melewati fase klinis (Linnakoski et al., 2018). Di sisi lain, senyawa bioaktif yang diisolasi dari sumber alami menawarkan keragaman yang luas dan belum banyak dijelajahi struktur kimianya (Strobel \& Daisy, 2003). Sejak 25 tahun terakhir, senyawa bioaktif dari banyak tanaman obat tradisional telah diskrining aktivitas antivirusnya (Jassim \& Naji, 2003). Salah satu sumber penemuan senyawa bioaktif ialah senyawa yang diisolasi dari kapang, terutama kapang yang tumbuh di lingkungan unik seperti kapang endofit. Kapang endofit adalah kapang yang hidup di dalam jaringan tanaman inangnya tanpa menimbulkan gejala sakit pada inangnya (Tan \& Zou, 2001). Selain itu, kapang endofit berpotensi menghasilkan beberapa senyawa aktif baru yang berpotensi digunakan sebagai antivirus.
Penemuan dan karakterisasi senyawa aktif dari kapang endofit yang memiliki aktivitas antivirus telah berkembang dan beberapa senyawa memiliki potensi yang menjanjikan (Linnakoski et al., 2018). Oleh karena itu tujuan dari penulisan makalah ini adalah untuk memaparkan beberapa kapang endofit yang menghasilkan senyawa antivirus terhadap virus yang menginfeksi manusia, mekanisme aksi antivirus dan tantangan dalam pengembangan senyawa antivirus asal kapang endofit.

\section{PEMBAHASAN}

Beberapa jenis virus merupakan penyebab infeksi pada manusia. Berikut ini merupakan beberapa senyawa aktif antivirus yang telah berhasil diisolasi dari kapang endofit. Senyawa aktif tersebut memiliki aktivitas penghambatan terhadap beberapa virus yang menginfeksi manusia. Adapun pengelompokan senyawa aktif antivirus dari kapang endofit didasarkan pada jenis virus yang menginfeksi.

\section{Anti-HIV}

Virus HIV (Human Immunodeficiency Virus) merupakan virus dari keluarga Retroviridae yang menyerang sistem kekebalan tubuh penderitanya. Penyakit yang disebabkan oleh infeksi virus HIV disebut AIDS (Acquired immunodeficiency syndrome). Meskipun berbagai upaya telah dilakukan untuk mencegah, mengobati, dan untuk lebih memahami penyakit ini, penyakit ini tetap menjadi salah satu penyebab utama morbiditas dan mortalitas di seluruh dunia (Bashyal et al., 2014). Beberapa senyawa antivirus HIV telah berhasil diisolasi dari beberapa kapang endofit.

Senyawa antivirus yang diisolasi dari Alternaria tenuissima QUE1Se, kapang endofit asal tanaman Quercus emoryi yaitu altertoxin V, salah satu metabolit baru yang ditemukan dalam penelitian ini, menunjukkan konsentrasi penghambatan $50 \%\left(\mathrm{IC}_{50}\right)$ terendah sebesar 0,09 
$\mu \mathrm{M}$. Metabolit aktif HIV lainnya, altertoxin I, II, III menunjukkan nilai IC $_{50}$ yang lebih tinggi yaitu 1,42; 0,21 dan 0,29 $\mu \mathrm{M}$, (Bashyal et al., 2014). Kapang endofit Periconia sp. F-31 yang diisolasi dari tanaman obat Annona muricata telah dilaporkan menghasilkan senyawa yang berpotensi sebagai antivirus HIV. Senyawa pericoannosin $A$ dan perikoniasin $F$ yang dihasilkan telah menunjukkan aktivitas anti-HIV dengan nilai IC $_{50}$ masing-masing sebesar 69,6 dan 29,2 $\mu \mathrm{M}$ (Zhang et al., 2015). Selain itu, senyawa asperphenalenone $A$, asperphenalenone $D$, cytochalasin $Z_{8}$ dan epicocconigrone $A$ yang diisolasi dari kapang endofit Aspergillus sp. CPCC 400735 asal tanaman Kadsura longipedunculata memiliki aktivitas anti-HIV dengan nilai IC $_{50}$ masing-masing sebesar 4,5; 2,4; 9,2 dan 6,6 $\mu \mathrm{M}$ (Pang et al., 2017).

Senyawa chartarutine $B$, chartarutine $G$, dan chartarutine $H$ yang didapatkan dari kapang endofit Stachybotrys chartarum strain WGC25C-6 hasil isolasi dari sponge Niphates sp., menunjukkan efek penghambatan yang signifikan terhadap replikasi HIV dalam uji infeksi satu siklus dengan nilai $\mathrm{IC}_{50}$ masing-masing sebesar 4,90; 5,57 dan 5,58 uM (Li et al., 2014). Senyawa antivirus stachybotrins $D$ juga telah berhasil diisolasi dari kapang endofit $S$. chartarum $\mathrm{MXH}-$ X73 yang didapatkan dari sponge Xestospongia testudinaris. Senyawa stachybotrins D menunjukkan efek penghambatan replikasi HIV1 dengan target enzim reverse transcriptase. Penelitian lebih lanjut menunjukkan bahwa stachybotrins $D$ dapat memblokir jenis virus yang resistan terhadap salah satu obat HIV, NNRTI, yaitu HIV-1 RT-K103N $_{\text {N }}$ HIV-1 RT-L100I,K103N, HIV-1 $_{\text {RT }}$ K103N,V108I, HIV-1 RT-K103N,G190A, dan HIV-

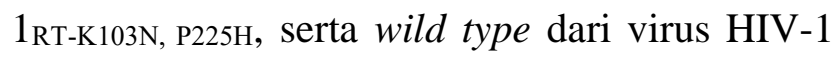
$\left(\mathrm{HIV}-1_{\mathrm{wt}}\right)$ dengan nilai $\mathrm{EC}_{50}$ masing-masing sebesar 7,0; 23,8; 13,3; 14,2; 6,2 dan 8,4 $\mu \mathrm{M}(\mathrm{Ma}$ et al., 2013).

\section{Anti-Virus Herpes}

Virus herpes (HSV) merupakan jenis virus yang termasuk dalam keluarga Herpesviridae dan sangat patogen terhadap manusia. Ada dua serotipe HSV pada manusia, yaitu HSV-1 dan
HSV-2. HSV-1 adalah agen penyebab utama infeksi wajah dengan ciri luka koreng ataupun luka seperti melepuh dan HSV-2, secara umum, adalah terkait dengan infeksi organ intim dan menyebabkan penyakit genital herpes (Xu et al., 2006). Belum ada metode yang benar-benar dapat memberantas virus herpes dari tubuh, tetapi obat antivirus dapat mengurangi frekuensi, durasi dan tingkat keparahannya. Selain itu, pemberian analgesik seperti ibuprofen dan parasetamol dapat mengurangi rasa sakit dan demam yang ditimbulkan (Mustafa et al., 2016). Beberapa senyawa aktif kandidat antivirus herpes telah berhasil diisolasi dari kapang endofit.

Kapang endofit Nigrospora sphaerica (No.831-1-2) telah diisolasi dari jaringan lichen Parmelinella wallichiana yang dikumpulkan dari Pegunungan Zixi, Provinsi Yunnan, Cina. Kapang endofit tersebut menghasilkan senyawa antivirus yang aktif terhadap virus herpes. Kedua senyawa tersebut adalah alternariol dan alternariol-9-metil eter yang menunjukkan aktivitas antivirus in vitro terhadap virus herpes simpleks (HSV) dengan nilai IC $_{50}$ masing-masing sebesar 13,5 dan 21,3 $\mu \mathrm{M}$ ( $\mathrm{He}$ et al., 2012). Kapang endofit, Pleospora tarda yang diisolasi dari tanaman obat Ephedra aphylla, memiliki aktivitas antivirus terhadap HSV-2 dengan aktivitas penghambatan sebesar 40,7\%. Penelitian lebih lanjut menunjukkan bahwa ekstrak kapang endofit tersebut menghasilkan senyawa antivirus alternariol and alternariol-(9)-methyl ether (Selim et al., 2018). Senyawa oblongolide $Z$ dan 2-Deoxy-4r-hydroxyoblongolide $X$ telah berhasil diisolasi dari kapang endofit Phomopsis sp. BCC 9789 dari daun pisang liar Musa acuminata yang berasal dari Taman Nasional Doi Suthep Pui, Provinsi Chiang Mai, Thailand. Oblongolide Z dan 2-Deoxy-4r-hydroxyoblongolide $X$ memiliki aktivitas anti-herpes simplex virus tipe 1 dengan nilai $\mathrm{IC}_{50}$ masing-masing sebesar 14 dan $76 \mu \mathrm{M}$ (Bunyapaiboonsri, et al., 2010).

Kapang endofit Aspergillus sp. strain SCSIO 41501 yang diisolasi dari koral lunak Melitodes squamata yang dikumpulkan dari Laut Cina Selatan, Sanya, Provinsi Hainan, Cina menghasilkan senyawa antivirus. Senyawa 
aspergillipeptides $D$ dan aspergillipeptides $E$ menunjukkan aktivitas antivirus terhadap jenis virus herpes simplex 1 (HSV-1) dengan nilai $\mathrm{IC}_{50}$ masing-masing sebesar 9,5 dan 19,8 uM di bawah konsentrasi non-sitotoksiknya terhadap sel Vero. Senyawa aspergillipeptides $D$ juga memiliki aktivitas antivirus terhadap isolat HSV-1 klinis yang resisten terhadap obat antivirus herpes asiklovir (Ma et al., 2017). Strain kapang endofit A. ruber (H-1) yang diisolasi dari koral lunak Gorgonia (XS-2009-13) yang dikumpulkan dari Kepulauan Xisha, China, menghasilkan senyawa antivirus isodihydroauroglaucin and flavoglaucin. Senyawa isodihydroauroglaucin dan flavoglaucin menunjukkan aktivitas antivirus yang signifikan terhadap virus HSV-1 dengan nilai $\mathrm{EC}_{50}$ masing-masing 4,73 dan $6,95 \mathrm{uM}$ (Liang et al., 2018).

\section{Anti-Virus Influenza}

Influenza adalah penyakit pernapasan yang disebabkan oleh virus yang terutama menyerang hidung, tenggorokan, bronkus dan, terkadang paru-paru. Virus ini berasal dari keluarga Orthomyxoviridae, bereproduksi dengan cepat, sering bermutasi, dan kadang-kadang terjadi infeksi silang antar spesies (Palese, 2004). Reformulasi vaksin tiap tahun berdasarkan pada perkiraan strain influenza yang akan datang selalu disertai dengan beberapa kegagalan karena pandemi virus yang tak terduga dan ketidakcocokan antigenik (Pica \& Palese, 2013). Meskipun demikian, beberapa senyawa aktif antivirus influenza asal kapang endofit patut dipertimbangkan.

Kapang endofit Phoma sp. strain YE3135 yang diisolasi dari akar Aconitum vilmorinianum menghasilkan dua senyawa antiviral. Kedua senyawa tersebut yaitu phomanolide dan (-)-6methoxymellein yang menunjukkan aktivitas antivirus terhadap virus influenza A (A/Puerto Rico/8/34, H1N1) dengan nilai $\mathrm{IC}_{50}$ masingmasing 2,96 dan 20,98 $\mu \mathrm{g} / \mathrm{mL}$ (Liu et al., 2019). Selain itu, kapang endofit Nigrospora sp. YE3033 yang diisolasi dari akar Aconitum carmichaeli yang dikumpulkan dari Lijiang, Provinsi Yunnan, China menghasilkan senyawa antivirus influenza.
Senyawa 6-O-demethyl-4-dehydroxyaltersolanol $A$; 4-dehydroxyaltersolanol A; altersolanol $C$, dan chermesinone $B$ menunjukkan efek penghambatan pada strain virus influenza A/Puerto Rico/8/34 (H1N1) dengan nilai $\mathrm{IC}_{50}$ masing-masing sebesar 2,59; 8,35; 7,82, dan 0,80 $\mu \mathrm{g} / \mathrm{mL}$ (Zhang et al., 2016).

Senyawa asteltoxin $E$ dan asteltoxin $F$ yang telah didapatkan dari kapang endofit Aspergillus sp. strain SCSIO XWS02F40 yang diisolasi dari sponge Callyspongia sp., asal Xuwen, Provinsi Guangdong, Cina memiliki aktivitas antivirus. Kedua senyawa tersebut menunjukkan penghambatan yang signifikan terhadap strain virus influenza $\mathrm{H} 3 \mathrm{~N} 2$ dengan nilai $\mathrm{IC}_{50}$ masingmasing sebesar 6,2 dan 8,9 $\mu \mathrm{M}$. Selain itu, senyawa asteltoxin $E$ juga menunjukkan aktivitas antivirus terhadap strain $\mathrm{H} 1 \mathrm{~N} 1$ dengan nilai $\mathrm{IC}_{50}$ sebesar 3,5 $\mu \mathrm{M}$ (Tian et al., 2016). Kapang Pestalotiopsis sp. strain AcBC2 yang merupakan endofit asal batang tanaman mangrove Aegiceras corniculatum yang dikumpulkan dari hutan mangrove Nansha, Provinsi Guangdong, Cina dan dilaporkan menghasilkan beberapa senyawa antivirus. Senyawa pestalol $A-D$, dan $3 b$-hydroxysterol memiliki aktivitas antivirus influenza (H3N2) dengan nilai IC $_{50}$ masing-masing sebesar 22,6; 27,7; 42,6; 48,0; dan 4,7 $\mu \mathrm{M}$. Sedangkan senyawa Pestalol A-E, transharzialactones $A$ dan $F$; 3b,5a, 9a-trihydroxy-7,22-en-ergost-6-one, dan 3b-hydroxy-sterol memiliki aktivitas antivirus influenza $(\mathrm{H} 1 \mathrm{~N} 1)$ dengan nilai $\mathrm{IC}_{50}$ masing-masing sebesar 18,$9 ; 28,7 ; 40,0 ; 48,0$; 39,$2 ; 37,6 ; 38,0 ; 36,9$; dan 2,2 $\mu \mathrm{M}$ (Sun et al. 2014).

Senyawa antivirus golongan seskuiterpen, 6 $\beta, 9 \alpha$-dihydroxy-14-p-nitrobenzoylcinnamolide telah diperoleh dari jamur endofit Aspergillus ochraceus Jcma1F17 yang diisolasi dari alga laut Coelarthrum sp. asal Kepulauan Paracel, Laut Cina Selatan. Senyawa tersebut merupakan senyawa baru yang menunjukkan aktivitas penghambatan sedang melawan virus, H3N2 dengan nilai $\mathrm{IC}_{50} 17,0 \mu \mathrm{M}$ (Fang et al., 2014). Kapang endofit Trichoderma sp. strain SCSIO41004 yang telah diisolasi dari sponge Callyspongia sp. asal wilayah laut dekat Xuwen, 
Provinsi Guangdong, Cina menghasilkan beberapa senyawa yang memiliki aktivitas antivirus. Senyawa trichbenzoisochromen A; 5,7dihydroxy-3-methyl-2-(2-oxopropyl)naphthalene -1,4-dione; ZSU-H85 A; 1, 3, 6-trihydroxy-8methytanthraquinone; dan 2,5-dimethyl-7hydroxy-Chromone memiliki penghambatan terhadap virus influenza H3N2 masing-masing sebesar 22,8; 3,9; 14,3; 0,4; dan 13,4\% (Pang et al., 2017).

\section{Anti-Virus Hepatitis}

Hepatitis adalah penyebab morbiditas dan mortalitas yang cukup besar pada populasi manusia, baik dari infeksi akut dan gejala sisa kronis yang menyertai. Karsinoma hepatoseluler, yang merupakan salah satu dari sepuluh kanker paling umum di seluruh dunia, terkait erat dengan hepatitis B, dan setidaknya di beberapa wilayah di dunia dengan virus hepatitis C (Zuckerman, 1996). Hepatitis C merupakan penyakit yang disebabkan oleh virus hepatitis dari keluarga Flaviviridae. Infeksi virus hepatitis $\mathrm{C}$ kronis (HCV) menjadi masalah global karena terapi yang kurang efektif dan kesulitan dalam mengembangkan vaksinnya. Jadi, ada kebutuhan mendesak untuk terapi baru yang ditargetkan secara spesifik untuk pengobatan infeksi HCV kronis (Hawas et al., 2013). Salah satu sumber bahan alam senyawa antivirus hepatitis ialah kapang endofit.

Kapang endofit Aspergillus versicolor yang diisolasi dari alga hijau Halimeda opuntia yang diperoleh dari Laut Merah, Mesir, menghasilkan senyawa antivirus. Senyawa emodin dan 1-metil emodin menunjukkan aktivitas antivirus terhadap virus hepatitis $\mathrm{C}$ (HCV NS3/4A) dengan nilai $\mathrm{IC}_{50}$ sebesar 22,5 dan 40,2 $\mu \mathrm{g} / \mathrm{mL}$ (Hawas et al., 2012). Sementara itu, kapang endofit $A$. versicolor yang diisolasi dari sponge hitam Spongia officinalis asal laut merah, Mesir, mengandung senyawa antivirus. Senyawa cyclo(L-Pro-L-Ile) dan cyclo-(L-Tyr-L-Pro) memiliki aktivitas yang kuat terhadap HCV NS3/4A protease dengan nilai $\mathrm{IC}_{50}$ masing-masing sebesar 13,4 dan $8,2 \mu \mathrm{g} / \mathrm{mL}$, sementara (-)-curvularin memiliki penghambatan ringan dengan nilai $\mathrm{IC}_{50}$ sebesar 37,4 $\mu \mathrm{g} / \mathrm{mL}$ (Ahmed et al., 2017).

Empat senyawa antivirus hepatitis $\mathrm{C}(\mathrm{HCV}$ protease) telah diisolasi dari kapang endofit Fusarium equiseti asal ganggang coklat Padina pavonica yang dikumpulkan dari daerah Laut Merah, pantai Hurgada Selatan, Mesir. Senyawa tersebut yaitu cyclo (L-Tyr-L-Pro), dan $\omega$ hydroxyemodin yang menunjukkan efek penghambatan paling kuat dengan nilai $\mathrm{IC}_{50}$ masing-masing sebesar 18,20 dan 10,7 $\mu \mathrm{g} / \mathrm{ml}$, sementara senyawa adenosin cordycepin dan Ara- $A$ menunjukkan penghambatan ringan dengan nilai IC $_{50}$ masing-masing sebesar 24,5 dan 22,3 $\mu \mathrm{g} / \mathrm{ml}$ (Hawas \& Al Farawati 2017). Kapang endofit Penicillium chrysogenum dari alga merah Ligora viscida asal laut merah, Mesir dilaporkan memiliki aktivitas antivirus hepatitis. Senyawa emodin dan $\omega$-Hydroxyemodin memiliki aktivitas penghambatan kuat terhadap HCV NS3-NS4A protease dengan nilai $\mathrm{IC}_{50}$ masing-masing sebesar 22,5 dan 10,6 $\mu \mathrm{g} / \mathrm{ml}$, sedangkan senyawa alatinone memiliki daya hambat yang lemah dengan nilai $\mathrm{IC}_{50}$ sebesar $100 \mu \mathrm{g} / \mathrm{ml}$ (Hawas et al., 2013). Dua metabolit sekunder baru, bernama 7 dehydroxyl-zinniol dan 20-hydroxylergosta-4,6,8 (14), 22-tetraen-3-one, telah berhasil diisolasi dari kapang endofit Alternaria solani yang didapatkan dari akar Aconitum transsectum. Senyawa 7-dehydroxyl-zinniol menunjukkan aktivitas antivirus hepatitis B (HBV) sedang terhadap sekresi HBsAg dengan nilai IC $_{50}$ sebesar 0,38 $\mu \mathrm{M}$ (Ai et al., 2012).

\section{Anti-Enterovirus}

Enterovirus (EV71) adalah virus yang berukuran kecil, tidak memiliki struktur amplop, berupa virus RNA untai tunggal positif dari keluarga Picornaviridae. Virus tersebut merupakan agen penyebab umum penyakit di tangan, kaki, dan mulut dan kadang - kadang memperparah penyakit dan penyebab komplikasi neurologis yang fatal pada anak kecil dan bayi (Ooi et al., 2010). Senyawa antienterovirus dilaporkan telah berhasil diisolasi dari kapang endofit. 
Senyawa antivirus golongan sesquiterpenoids, 6 $\beta, 9 \alpha$-dihydroxy-14-p-nitrobenzoylcinnamolide telah diperoleh dari jamur endofit Aspergillus ochraceus Jcma1F17 yang diisolasi dari alga laut Coelarthrum sp. dikoleksi dari Kepulauan Paracel, Laut Cina Selatan. Senyawa tersebut merupakan senyawa baru yang menunjukkan aktivitas penghambatan sedang melawan virus EV71, dengan nilai IC 50 sebesar 9,4 $\mu \mathrm{M}$ (Fang et al., 2014). Kapang endofit Trichoderma sp. strain SCSIO41004 yang diisolasi dari sponge Callyspongia sp. dikumpulkan dari wilayah laut dekat Xuwen, Provinsi Guangdong, Cina juga dilaporkan menghasilkan beberapa senyawa yang memiliki aktivitas antivirus. Senyawa trichbenzoisochromen A; 5,7-dihydroxy-3-methyl2-(2-oxopropyl)naphthalene-1,4-dione; ZSU-H85 A; 1, 3, 6-trihydroxy-8-methytanthraquinone; 2,5dimethyl-7-hydroxy-Chromone; dan 7-hydroxy-2(2'S-hydroxypropyl)- 5-methylchromone memiliki penghambatan enterovirus 71 masing-masing sebesar 25,18; 9,01; 63,93; 29,18; 20,30; dan 16,84\% (Pang et al., 2017).

Strain jamur Pestalotiopsis sp. ZJ-2009-7-6 yang diisolasi karang lunak Sarcophyton sp. yang dikumpulkan dari Pulau Yongxing di Laut Cina Selatan menghasilkan senyawa antivirus. Pestalotiolide A mempunyai aktivitas kuat antiEV71, dengan nilai $\mathrm{IC}_{50}$ sebesar 27,7 $\mu \mathrm{M}$. Senyawa 7-hidroksi-5-metoksi-4,6-dimetil-7-O$\beta$-Dgluco-pyranosyl-phthalide menunjukkan aktivitas antivirus terhadap EV71 dengan nilai $\mathrm{IC}_{50}$ sebesar 51,6 $\mu \mathrm{M}$. Senyawa 5'-O-asetil uridin dan 7-Hidroksi-5-metoksi-4,6-dimetil-7-O- $\alpha-L$ rhamnosyl-phthalide sama-sama memiliki aktivitas antivirus dengan nilai $\mathrm{IC}_{50}$ masingmasing sebesar 110 dan $110 \mu \mathrm{M}$ terhadap EV71 (Jia et al., 2015a). Sepasang dimer alkaloid enansiomer baru yaitu (+)-1 pestaloxazine $A$, dan (-)-1 pestaloxazine A telah diisolasi dari kapang endofit Pestalotiopsis sp. (ZJ-2009-7-6) asal karang lunak Sarcophyton sp. Berdasarkan aktivitas anti-EV71 (enterovirus 71) pada sel Vero secara in vitro menggunakan uji penghambatan CPE, senyawa (+)-1 pestaloxazine $A$, dan (-)-1 pestaloxazine $A$ menunjukkan aktivitas antivirus dengan nilai $\mathrm{IC}_{50}$ masing-masing sebesar 14,2 dan 69,1 $\mu \mathrm{M}$ (Jia et al., 2015b). P. vaccinia, kapang endofit asal bagian cabang tanaman mangrove Kandelia candel menghasilkan senyawa aktif antienterovirus. Senyawa tersebut adalah vaccinal $A$ yang mempunyai aktivitas penghambatan secara in vitro terhadap virus EV71 dengan nilai $\mathrm{IC}_{50}$ sebesar 19,2 $\mu \mathrm{M}$ (Wang et al., 2014).

\section{Anti-Respiratory Syncytial Virus}

Human Respiratory syncytial virus (RSV), anggota dari genus Pneumovirus dalam keluarga Paramyxoviridae, adalah penyebab utama infeksi saluran pernapasan bawah pada bayi dan anakanak di seluruh dunia (Avendano et al., 2003). RSV bertanggung jawab atas infeksi tertinggi pada saluran pernapasan bawah anak-anak dan bayi dan menyebabkan sekitar 100.000 anak terinfeksi dengan 250 kematian setiap tahun di Amerika Serikat (Falsey \& Walsh, 2000).

Strain kapang Pestalotiopsis sp. ZJ-2009-7-6, endofit yang diisolasi karang lunak Sarcophyton sp. yang dikumpulkan dari Pulau Yongxing di Laut Cina Selatan, menghasilkan senyawa antivirus. Pestalotiolide A mempunyai aktivitas antivirus RSV dengan nilai $\mathrm{IC}_{50} 80,9 \mu \mathrm{M}$. Senyawa 7 - hidroksi - 5-metoksi-4,6-dimetil7-O- $\beta$-Dgluco-pyranosyl-phthalide menunjukkan aktivitas antivirus yang kuat terhadap RSV dengan nilai $\mathrm{IC}_{50}$ sebesar 25,6 $\mu \mathrm{M}$. sedangkan senyawa 7 - Hydroxy - 5 - methoxy - 4,6 dimethylphthalide memiliki aktivitas antivirus terhadap RSV dengan nilai $\mathrm{IC}_{50}$ sebesar 21,0 $\mu \mathrm{M}$. (Jia et al., 2015a). Kapang endofit $P$. thea yang diisolasi dari daun segar Fagara zanthoxyloides mengandung senyawa antivirus. Senyawa chloroisosulochrin menunjukkan aktivitas kuat terhadap RSV dengan $\mathrm{IC}_{50} 4,22 \mu \mathrm{M}$, sedangkan ficipiron $A$ menunjukkan aktivitas sedang dengan $\mathrm{IC}_{50} 45,00 \mu \mathrm{M}$ (Uzor et al., 2016).

\section{Anti-Coxsackievirus}

Virus Cox-B3 merupakan virus anggota keluarga Picornaviridae, Coxsackievirus (Cox), dibagi menjadi Cox A dan Cox B yang diketahui menyebabkan infeksi perinatal (James, 2014). Cox A cenderung menginfeksi kulit dan selaput lendir, menyebabkan herpangina dan penyakit 
tangan-kaki-dan-mulut, sedangkan Cox B cenderung menginfeksi jantung, dan hati, menyebabkan miokarditis, perikarditis, dan hepatitis. Strain jamur Pestalotiopsis sp. ZJ-20097-6 yang diisolasi karang lunak Sarcophyton sp. yang dikumpulkan dari Pulau Yongxing di Laut Cina Selatan menghasilkan senyawa antivirus. Senyawa 7 - Hydroxy - 5 - methoxy - 4,6 dimethylphthalide memiliki aktivitas antivirus terhadap Cox-B3 dengan nilai IC $_{50}$ sebesar 19,6 $\mu \mathrm{M}$. Senyawa 5'-O-asetil uridin dan 7-Hidroksi-5metoksi-4,6-dimetil-7-O- $\alpha$-L-rhamnosyl-phthalide sama-sama memiliki aktivitas antivirus dengan nilai $\mathrm{IC}_{50}$ sebesar 127,5 dan $95,9 \mu \mathrm{M}$ terhadap Cox-B3 (Jia et al., 2015a).

\section{Mekanisme Aksi Senyawa Antivirus}

Mekanisme penghambatan antivirus berhubungan dengan siklus hidup virus dan proses terkait lainnya. Beberapa antivirus bekerja dengan cara mengganggu proses penempelan virus pada sel inang dengan cara merusak reseptor ataupun berperan sebagai analog (menyerupai) reseptor. Pada antivirus hepatitis $\mathrm{C}(\mathrm{HCV})$, senyawa antivirus akan menempel pada protein E1/E2 yang berperan membantu HCV untuk melekat pada reseptor yang ada di sel inang. Dengan penempelan tersebut, maka HCV gagal menempel pada permukaan sel inang (Irshad et al., 2018). Proses selanjutnya ialah proses pelepasan materi genetik virus ke dalam sitoplasma sel inang yang beberapa diantaranya melibatkan kapsid virus. Proses ini juga menjadi target kerja dari senyawa antivirus. Kapsid merupakan salah satu target dari senyawa antivirus. Inhibitor kapsid adalah senyawa yang dapat berintegrasi dalam sisi hidrofobik kapsid terutama pada virus dari keluarga Picornaviridae. Proses perlekatan tersebut menyebabkan imobilisasi dan kompresi kapsid, di mana virus tidak dapat melepaskan RNA ke dalam sel inang (De Palma et al., 2008).

Setelah berhasil mengeluarkan materi gentiknya ke dalam sel inang, virus akan melakukan perbanyakan diri. Proses selama perbanyakan diri mempunyai beberapa tahapan dan proses ini dapat dijadikan target dari senyawa antivirus. HIV merupakan virus yang materi genetiknya berupa utas tunggal RNA. Virus ini dapat menginfeksi sel inang karena mempunyai enzim reverse transcriptase yang mengubah RNA menjadi DNA. Oleh karena itu enzim tersebut dapat dijadikan target senyawa antivirus untuk menghambat perkembangan HIV. Senyawa penghambat ini secara kompetitif mencegah enzim reverse transcriptase HIV dan berperan sebagai terminator urutan sintesis DNA. Sintesis DNA virus berhenti karena terjadi perubahan struktur dari analog nukleotida (seperti hilangnya kelompok 3'-OH) sehingga akan mencegah ikatan fosfodiester 5' ke 3' yang diperlukan untuk perpanjangan urutan DNA (Boyer et al., 2015). Proses selanjutnya ialah perakitan virus menjadi bentuk sempurna seperti saat sebelum menginfeksi sel inang. Proses perakitan virus ini merupakan salah satu target penghambatan dari beberapa senyawa antivirus. Pada virus herpes golongan cytomegalovirus (CMV), target lain yang telah dieksploitasi adalah kompleks CMV terminase, yaitu penghambatan yang mengganggu proses perakitan virus. Kompleks ini diperlukan untuk membelah unit genom CMV yang dihasilkan dan kemudian dikemas ke dalam kapsul virus yang sudah terbentuk sebelumnya (Borst et al., 2013).

Secara lebih mendalam, mekanisme suatu senyawa aktif dalam menghambat perkembangan virus dapat diketahui dari ikatan antara ligan senyawa tersebut dengan protein virus target. Salah satu cara untuk mengetahui ikatan tersebut adalah dengan metode in silico melalui molecular docking. Kondisi terkini yang terjadi adalah terjadinya pandemi COVID-19, penyakit infeksi pernapasan akut akibat virus SARS-CoV-2. Penggunaan senyawa aktif antivirus yang berasal dari kapang endofit, yang secara in vitro memiliki aktivitas antivirus, menarik untuk diketahui simulasi penghambatannya terhadap virus SARSCov-2. Senyawa kurkumin yang telah diisolasi dari kapang endofit EZG0807 asal akar tanaman Curcuma wenyujin (Yan et al., 2014) dan katekin yang diisolasi dari kapang endofit Annulohypoxylon ilanense (Cheng et al., 2013) berpotensi sebagai anti-SARS-Cov-2 secara in 
silico. Katekin dan kurkumin memiliki ikatan kuat dengan protein $\mathrm{S}$ virus. Ikatan hidrogen konvensional dan ikatan hidrogen-karbon memfasilitasi pengikatan antara ligan (kurkumin dan katekin) dengan protein S. Interaksi ligan dan protein S sangat kuat di sisi Receptor Binding Domain (RBD) dari protein S. Sisi RBD dihubungkan oleh gugus keto dari kurkumin dengan afinitas yang tinggi pada asam amino Leu335 melalui ikatan hidrofobik. Sedangkan residu asam amino Arg-634 dan Val-635 dekat sisi RBD memiliki afinitas yang tinggi terhadap gugus hidroksil dari katekin (Jena et al., 2020).

Selain itu, senyawa norquinadoline $A$ yang diiolasi dari kapang endofit Cladosporium sp. PJX-41 asal tanaman mangrove memiliki penghambatan terhadap protein $\mathrm{PL}^{\text {pro }}$ virus SARS-CoV-2 secara in silico. Senyawa norquinadoline $A$ menempel erat ke situs pengikatan PLpro, sebagian besar distabilkan oleh gaya van der Waals. Dua ikatan-H semakin memperkuat interaksinya dengan enzim, khususnya antara oksigen karbonil dari inti pyrazinoquinozolinedione dengan asam amino Lys711 dan Arg712 (Quimque et al., 2020). Senyawa quanidoline $B$ yang berasal dari kapang endofit yang sama dengan norquinadoline $A$. Senyawa quanidoline $B$ menempel ke situs pengikatan protein RNA-directed RNA polymerase ( $\mathrm{RdRp}$ ) adalah akibat peran serta dari dua bagian tertentu. Dalam inti quinazolinone nya, ikatan-H dapat diamati antara asam amino Gln73 serta interaksi $\pi$-kation dan $\pi$-alkil masingmasing dengan asam amino Arg569 dan Ala686. Bagian indoline dari quanidoline $B$ terikat pada residu asam amino Tyr689, Ala580 dan Ala688 melalui interaksi $\pi-\pi$ stacking dan interaksi $\pi$ alkil. Target penghambatan lainnya adalah protein non struktural 15 (nsp15). Senyawa isochaetochromin D1 yang diisolasi dari kapang endofit Fusarium sp. asal tanaman Podocarpus dacryoides dilaporkan mampu menghambat protein non struktural SARS-CoV-2 secara in silico. Senyawa isochaetochromin D1 melekat pada domain pengikatan melalui ikatan-H dengan asam amino Val292 dan residu katalitik His250. Beberapa interaksi $\pi$ diamati karena adanya inti poliaromatik pada isochaetochromin D1. Lebih lanjut, daya van der Waals meningkatkan stabilitas kompleks enzim-ligan, khususnya terhadap His235 dan Lys290 bersama dengan residu lainnya di daerah katalitik (Jena et al., 2020).

\section{Tantangan Pengembangan Senyawa Aktif Antivirus Asal Kapang Endofit}

Standarisasi biosintesis senyawa aktif secara biologis, serta peningkatan produksi ke skala industri berkaitan dengan kompleksitas biologi dan ekologi kapang. Interaksi antarspesies diketahui mempengaruhi metabolisme kapang di lingkungan aslinya (Kusari et al., 2014), sehingga perlu strategi dalam penumbuhan kapang di media fermentasi sintetik, salah satunya dengan teknik kultur ganda ataupun campuran (Cichewich, 2010). Selain penggunaan media fermentasi cair dalam menghasilkan senyawa metabolit sekunder antivirus potensial, kapang endofit juga dapat ditumbuhkan pada media padat. Penggunaan media padat dari limbah industri agro memberikan peluang yang lebih ramah lingkungan dan biaya yang lebih rendah dalam proses produksi senyawa antivirus yang berasal dari kapang (Chen et al., 2012). Strategi lainnya adalah dengan memanfaatkan teknik metabolomik guna memahami regulasi senyawa metabolit sekunder yang pada akhirnya akan meningkatkan jumlah senyawa target yang dihasilkan (Harvey et al., 2015).

Penelitian berbasis genom telah memberikan wawasan baru dan menunjukkan bahwa banyak klaster gen yang terlibat dalam biosintesis metabolit sekunder tidak diekspresikan dengan baik dalam kondisi kultur pertumbuhan standar/fermentasi yang secara umum digunakan untuk mendapatkan metabolit sekunder (Bergmann et al., 2007). Untuk mengaktifkan klaster gen biosintetik yang tidak terekspresi, mengubah kondisi media pertumbuhan (seperti sumber karbon dan nitrogen, suhu, cahaya, $\mathrm{pH}$ dan aerasi) telah digunakan sebagai rangsangan agar gen-gen tersebut dapat diekspresikan. Namun, regulasi metabolisme sekunder merupakan jalur biosintesis yang sangat 
kompleks, dan pengubahan kondisi media pertumbuhan tidak selalu akan merangsang sebagian besar kelompok gen yang bersifat dorman dan juga cocok diterapkan pada seluruh spesies kapang (Brakhage, 2013). Saat ini, strategi genome mining memberikan kemungkinan baru untuk memahami dasar genetik dari produksi metabolit sekunder dan mengembangkan strategi untuk aktivasi jalur metabolisme yang belum aktif (Bergmann et al., 2007).

Tantangan selanjutnya adalah metode untuk mendapatkan senyawa murni. Penapisan produk senyawa aktif dari bahan alam seperti kapang endofit akan membutuhkan tenaga, waktu dan biaya yang tidak sedikit. Selain itu, perbedaan konsentrasi antara metabolit sekunder yang berbeda menimbulkan permasalahan saat identifikasi (Ciesla \& Moaddel, 2016). Penggunaan instrumen analisis yang semakin canggih akan mengurangi tantangan yang dihadapi. Salah satunya adalah penggunaan instrumen Liquid Chromatography-Nucelar Magnetic Resonance (LC-NMR) untuk elusidasi struktur kimia senyawa aktif. Teknik ini telah banyak diterapkan dalam analisis campuran kompleks yang mengandung sejumlah komponen senyawa yang tidak diketahui seperti berbagai jenis metabolit dan pengotor dalam obat-obatan, bahan alam, maupun polimer sintetis (Modi et al., 2016). Pada penentuan struktur senyawa aktif, masih ada sejumlah kekurangtepatan penentuan struktur dari produk alami yang dilaporkan dalam literatur. Salah satu alternatifnya adalah penggunaan program Computer-Assisted Structure Elucidation (CASE) yang dapat meminimalkan risiko ini dengan menghasilkan semua struktur yang konsisten dengan input data dan menampilkan peringkat struktur dalam urutan probabilitas. Pendekatan metode ini berhasil menentukan struktur untuk produk bahan alam yang kompleks (Burns et al., 2018).

Senyawa antivirus asal kapang yang terbukti efektif secara in vitro menurut persyaratan farmakologi yang berlaku akan dilanjutkan menuju pengujian in vivo pada hewan coba. Namun, sejauh ini uji klinis penggunaan obat- obatan asal kapang yang memenuhi standar jumlahnya masih sangat sedikit (Zhou et al., 2005; Gargano et al., 2017). Oleh karena itu, diharapkan kedepannya pengujian senyawa antivirus dari kapang endofit secara in vivo dan uji klinis semakin banyak dilakukan. Sehingga potensi senyawa aktif antivirus asal kapang endofit tidak hanya berhenti pada tahap eksplorasi dan pengujian skala laboratorium saja.

\section{SIMPULAN}

Kapang endofit memiliki potensi yang besar sebagai sumber senyawa aktif antivirus. Penelitian tentang eksplorasi senyawa antivirus baru, mekanisme aksi, pengembangan senyawa antivirus yang telah ada dan pengujian senyawa antivirus hingga disetujui penggunaanya secara klinis menjadi tantangan di masa yang akan datang.

\section{KEPUSTAKAAN}

Ahmed EF, Rateb ME, El-Kassem LTA, Hawas UW. 2017. Anti-HCV protease of diketopiperazines produced by the red sea sponge-associated fungus Aspergillus versicolor. App. Biochem. Microbiol. 53(1): 101-106.

Ai HL, Zhang LM, Chen YP, Zi SH, Xiang H, Zhao DK, Shen Y. 2012. Two new compounds from an endophytic fungus Alternaria solani. J. Asian Nat. Prod. Res.14(12): 1144-1148.

Avendano L, Palomino M, Carmen L. 2003. Surveillance for respiratory syncytial virus in infants hospitalized for acute lower respiratory infection in Chile (1989 to 2000). J. Clin. Microbiol. 41: 4879-4882.

Bashyal BP, Wellensiek BP, Ramakrishnan R, Faeth SH, Ahmad N, Gunatilaka AAL. 2014. Altertoxins with potent anti-HIV activity from Alternaria tenuissima QUE1Se, a fungal endophyte of Quercus emoryi. Bioorg. Med. Chem. 22(21): 6112-6116.

Bergmann S, Schümann J, Sherlach K, Lange C, Brakhage AA, Hertweck C. 2007. Genomicsdriven discovery of PKS-NRPS hybrid 
metabolites from Aspergillus nidulans. Nat. Chem. Biol. 3: 213-217.

Borst EM, Kleine-Albers J, Gabaev I, Babic M, Wagner K, Binz A, Degenhardt I, Kalesse M, Jonjic S, Bauerfeind R, Messerle M. 2013. The human cytomegalovirus UL51 protein is essential for viral genome cleavagepackaging and interacts with the terminase subunits pUL56 and pUL89. J. Virol. 87(3): 1720-1732.

Boyer PL, Sarafianos SG, Clark PK, Arnold E, Hughes SH. 2006. Why do HIV-1 and HIV-2 use different pathways to develop AZT resistance?. PLoS Pathog. 2:e10.

Brakhage AA. 2013. Regulation of fungal secondary metabolism. Nat. Rev. Microbiol. 11: 21-32.

Bunyapaiboonsri T, Yoiprommarat S, Srikitikulchai P, Srichomthong K, Lumyong S. 2010. Oblongolides from the endophytic fungus Phomopsis sp. BCC 9789. J. Nat. Prod. 73: 55-59.

Burns D, Mazzola E, Reynolds W. 2019. The role of computer-assisted structure elucidation (CASE) programs in the structure elucidation of complex natural products. Nat. Prod. Rep. 36. Doi: $10.1039 / \mathrm{C} 9 \mathrm{NP} 00007 \mathrm{~K}$.

Chen S, Xu J, Liu C, Zhu Y, Nelson DR, Zhou S, Li C, Wang L, Guo X, Sun Y, Luo H, Li Y, Song J, Henrissat B, Levasseur A, Qian J, Li J, Luo X, Shi L, He L, Xiang L, Xu X, Niu Y, Li Q, Han MV, Yan H, Zhang J, Chen H, Lv A, Wang Z, Liu M, Schwartz DC, Sun C. 2012. Genome sequence of the model medicinal mushroom Ganoderma lucidum. Nat. Commun. 3: 913.

Cheng MJ, Wu MD, Chen JJ, Hsieh SY, Yuan GF, Chen IS, Chang CW. 2013. Secondary metabolites from the endophytic fungus of Annulohypoxylon ilanense. Chem. Nat. Compd. 49: 523-525.

Cichewicz RH. 2010. Epigenome manipulation as a pathway to new natural product scaffolds and their congeners. Nat. Prod. Rep. 27: 1122.
Ciesla L, Moaddel R. 2016. Comparison of analytical techniques for the identification of bioactive compounds from natural products. Nat. Prod. Rep. 33(10): 1131-1145.

Clercq ED. 2002. Strategies in the design of antiviral drugs. Nat. Rev. 1: 13-25.

De Palma AM, Vliegen I, De Clercq E, Neyts J. 2008. Selective inhibitors of picornavirus replication. Med. Res. Rev. 28: 823-884.

Falsey AR, Walsh EE. 2000. Respiratory syncytial virus infection in adults. Clin. Microbiol. Rev. 13(3): 371-384.

Fang W, Lin X, Zhou X, Wan J, Lu X, Yang B, Ai W, Lin J, Zhang T, Tu Z, Liu Y. 2014. Cytotoxic and antiviral nitrobenzoyl sesquiterpenoids from the marine-derived fungus Aspergillus ochraceus Jcma1F17. Med. Chem. Commun. 5(6): 679-832.

Gargano M, van Griensven LJLD, Isikhuemhen OS, Lindequist U, Venturella G, Wasser SP, Zervakis GI. 2017. Medicinal mushrooms: valuable biological resources of high exploitation potential. Plant Biosyst. 151: 548-565.

Harvey AL, Edrada-Ebel R, Quinn RJ. 2015. The re-emergence of natural products for drug discovery in the genomics era. Nat. Rev. Drug Discov. 14: 111-129.

Hawas UW, Al-Farawati R. 2017. Chemical constituents and antiviral activity from marine endophytic fungi from red sea alga Padina pavonica. J. Chem. Soc. Pak. 39(3): 478-483.

Hawas UW, El-Beih AA, El-Halawany AM. 2012. Bioactive anthraquinones from endophytic fungus Aspergillus versicolor isolated from red sea algae. Arch. Pharm. Res. 35(10): 1749-1756.

Hawas UW, El-Halawany AM, Ahmed EF. 2013. Hepatitis C virus NS3-NS4A protease inhibitors from the endophytic Penicillium chrysogenum isolated from the red alga Liagora viscida. Z. Naturforsch. 68c: $355-$ 366.

He JW, Chen GD, Gao H, Yang F, Li XX, Peng T, Guo LD, Yao XS. 2012. Heptaketides with 
antiviral activity from three endolichenic fungal strains Nigrospora sp., Alternaria sp. and Phialophora sp. Fitoterapia. 83: 10871091.

Irshad M, Gupta P, Irshad K. 2018. Molecular targeting of antiviral drugs used against hepatitis $\mathrm{C}$ virus infection. Hepatoma Res. 4: 23.

James CPK. 2014. Enterovirus, Parechovirus, and Saffold Virus Infection. J.D. In: Cherry GJ, Harrison SL, Kaplan WJ, Steinbach, Hotez PJ (eds) Textbook of Pediatric Infectious Diseases. $7^{\text {th }}$ ed. Elsevier Saunders: Philadelphia, 2051-2108.

Jassim SA, Naji MA. 2003. Novel antiviral agents: a medicinal plant perspective. $J$. Appl. Microbiol. 95: 412-427.

Jena AB, Kanungo N, Nayak V, Chainy G, Dandapat J. 2020. Catechin and curcumin interact with corona (2019-nCoV/SARSCoV2) viral S protein and ACE2 of human cell membrane: insights from Computational study and implication for intervention (preprint). Research Square. Doi: 10.21203/rs.3.rs-22057/v1.

Jia YL, Guan FF, Ma J, Wang CY, Shao CL. 2015a. Pestalotiolide A, a new antiviral phthalide derivative from a soft coral-derived fungus Pestalotiopsis sp. Nat. Prod. Sci. 21(4): 227-230.

Jia YL, Wei MY, Chen HY, Guan FF, Wang CY, Shao CL. 2015b. (+)- and (-)-pestaloxazine A, a pair of antiviral enantiomeric alkaloid dimers with a symmetric spiro[oxazinane piperazinedione] skeleton from Pestalotiopsis sp. Org. Lett. 17(17): 42164219.

Kusari S, Singh S, Jayabaskaran C. 2014. Biotechnological potential of plantassociated endophytic fungi: hope versus hype. Trends Biotechnol. 32: 297-303.

Li Y, Liu D, Cen S, Proksch P, Lin W. 2014. Isoindolinone-type alkaloids from the sponge-derived fungus Stachybotrys chartarum. Tetrahedron. 70: 7010e7015.
Liang TM, Fang YW, Zheng JY, Shao C.L. 2018. Secondary metabolites isolated from the gorgonian-derived fungus Aspergillus ruber and their antiviral activity. Chem. Nat. Compd. 54(3): 559-561.

Linnakoski R, Reshamwala D, Veteli P, CortinaEscribano M, Vanhanen H, Marjomäki V. 2018. Antiviral agents from fungi: diversity, mechanisms and potential applications. Front. Microbiol. 9:2325.

Liu SS, Jiang JX, Huang R, Wang YT, Jiang BG, Zheng KX, Wu SH. 2019. A new antiviral 14-nordrimane sesquiterpenoid from an endophytic fungus Phoma sp. Phytochem. Lett. 29: 75-78.

Ma X, Li L, Zhu T, Ba M, Li G, Gu Q, Guo Y, Li D. 2013. Phenylspirodrimanes with anti-HIV activity from the sponge-derived fungus Stachybotrys chartarum MXH-X73. J. Nat. Prod. 76(12): 2298-2306.

Ma X, Nong XH, Ren Z, Wang J, Liang X, Wang L, Qi SH. 2017. Antiviral peptides from marine gorgonian-derived fungus Aspergillus sp. SCSIO 41501. Tetrahedron Lett. 58: 1151-1155.

Modi VS, Siddique SS, Prajapati P, Basuri T, Patel DR. 2016. A technique expanding the limits of structure elucidation: LC-NMR. Int J Pharm Sci Rev Res. 39. 148-155.

Mustafa M, Illzam EM, Muniandy RK, Sharifah AM, Nang MK, Ramesh B. 2016. Herpes simplex virus infections, pathophysiology and management. IOSR JDMS. 15(7): 85-91.

Ooi MH, Wong SC, Lewthwaite P, Cardosa MJ, Solomon T. 2010. Clinical features, diagnosis, and management of enterovirus 71. Lancet Neurol. 9(11): 1097-1105.

Palese P. 2004. Influenza: old and new threats. Nat. Med. 10: S828-S87.

Pang X, Zhao JY, Fang XM, Zhang T, Zhang DW, Liu HY, Su J, Cen S, Yu LY. 2017. Metabolites from the plant endophytic fungus Aspergillus sp. CPCC 400735 and their anti-HIV activities. J. Nat. Prod. 80: 2595-2601. 
Pica N, Palese P. 2013. Toward a universal influenza virus: prospects and challenges. Annu. Rev. Med. 64: 189-202.

Quimque MT, Notarte K, Fernandez RA, Mendoza M, Liman RA, Lim JA, Pilapil L, Ong JK, Pastrana A, Macabeo A. 2020. Not One, But Five: Virtual Screening-Driven Drug Discovery of SARS-CoV2 Enzyme Inhibitors Targeting Viral Attachment, Replication and Post-Translational Infection Mechanisms (preprint). ChemRxiv. Doi: 10.26434/chemrxiv.12170424.v1.

Selim KA, Elkhateeb WA, Tawila AM, El-Beih AA, Abdel-Rahman TM, El-Diwany AI, Ahmed EF. 2018. Antiviral and antioxidant potential of fungal endophytes of Egyptian medicinal plants. Fermentation. 4: 49.

Strobel G, Daisy B. 2003. Bioprospecting for microbial endophytes and their natural products. Microbiol. Mol. Biol. Rev. 67: 491502.

Sun JF, Lin X, Zhou XF, Wan J, Zhang T, Yang B, Yang XW, Tu Z, Liu Y. 2014. Pestalols A-E, new alkenyl phenol and benzaldehyde derivatives from endophytic fungus Pestalotiopsis sp. AcBC2 isolated from the Chinese mangrove plant Aegiceras corniculatum. J. Antibiot. 67: 451-457.

Tan R, Zou W. 2001. Endophytes: a rich source of functional metabolites. Nat. Prod. Rep. 18: 448-459.

Tian YQ, Lin XP, Wang Z, Zhou XF, Qin XC, Kaliyaperumal K, Zhang TY, Tu ZC, Liu Y. 2016. Asteltoxins with antiviral activities from the marine sponge-derived fungus Aspergillus sp. SCSIO XWS02F40. Molecules. 21: e34.

Uzor P, Odimegwu D, Ebrahim W, Osadebe P, Nwodo N, Okoye F, Liu Z, Proksch P. 2016. Anti-respiratory syncytial virus compounds from two endophytic fungi isolated from Nigerian medicinal plants. J. Drug Res. 66: 527-532.

Wang J, Wei X, Lu X, Xu F, Wan J, Lin X, Zhou X, Liao S, Yang B, Tu Z, Liu Y. 2014. Eight new polyketide metabolites from the fungus Pestalotiopsis vaccinii endogenous with the mangrove plant Kandelia candel (L.) Druce. Tetrahedron. 70: $9695 \mathrm{e} 9701$.

Xu F, Sternberg MR, Kottiri BJ, McQuillan GM, Lee FK, Nahmias AJ, Berman SM, Markowitz LE. 2006. Trends in herpes simplex virus type 1 and type 2 seroprevalence in the United States. JAMA. 296: 964-973.

Yan J, Qi N, Wang S, Gadhave K, Yang S. 2014. Characterization of secondary metabolites of an endophytic fungus from Curcuma wenyujin. Curr. microbiol. 69: 740-744.

Zhang D, Tao X, Chen R, Liu J, Li L, Fang X, Yu L, Dai J. 2015. Pericoannosin A, a polyketide synthase-nonribosomal peptide synthetase hybrid metabolite with new carbon skeleton from the endophytic fungus Periconia sp. Org. Lett. 17(17): 4304-4307.

Zhang SP, Huang R, Li FF, Wei HX, Fang XW, Xie XS, Lin DG, Wu SH, He J. 2016. Antiviral anthraquinones and azaphilones produced by an endophytic fungus Nigrospora sp. from Aconitum carmichaeli. Fitoterapia. 112: 85-89.

Zhou S, Gao Y, Chan E. 2005. Clinical trials for medicinal mushrooms: experience with Ganoderma lucidum (W.Curt.:Fr.) Lloyd (Lingzhi Mushroom). Int. J. Med. Mushrooms. 7: 111-118.

Zuckerman AJ. 1996. Hepatitis Viruses. In: Baron S (ed) Medical Microbiology. 4th edition. Chapter 70. University of Texas Medical at Galveston: Texas, 1-31. 